\title{
Notes on Palaearctic Scythrididae, with description of two new species (Lepidoptera: Scythrididae)
}

\author{
Kari Nupponen
}

Nupponen, K. 2005: Notes on Palaearctic Scythrididae, with description of two new species (Lepidoptera: Scythrididae). — Entomol. Fennica 16: 165-174.

In this paper 13 species of the family Scythrididae from Turkey, Ukraine, Russia, Mongolia and Jordan are treated. Scythris hebesella sp. n. is described from central Turkey, S. hemicycliella sp. n. from the Altai Mountains, and a previously unknown female of $S$. elenae Nupponen, 2000 from the southern Ural Mountains. $S$. caroxylella Falkovitch, 1969 is reported as new to Mongolia, S. eversmanni Nupponen \& Nupponen, 2000 as new to Ukraine, and four species as new to Jordan, and further records of three rare scythridids from the southern Ural Mountains. The determination of the bifissella species complex is discussed and genitalia photographs of its four taxa are presented.

K. Nupponen, Miniatontie 1 B 9, FI-02360 Espoo, Finland

Received 19 February 2004, accepted 30 November 2004

\section{Introduction}

The scythridid fauna of central parts of Russia has been studied quite intensively during the recent years. However, since the results from trips to the southern Ural Mountains were published (Nupponen et al. 2000), no further species of scythridids have been found from the Ural region, though few noteworthy species have been recorded. Studies on the material from Turkey and various localities in the Palaearctic region revealed interesting results, including two undescribed species. The results of these studies are summarized in this paper.

\section{Examined species}

Scythris amplexella Bengtsson, 2002

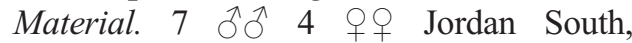
Al'Agaba env., 300 m NN, 12-16.II.2001, leg. Krüger, Saldaitis \& Saldaitiene. 1 \&. Sinai, Na'ama env., h-400 m., 21-31.I.2003, A. Saldai- tis leg. 1 genitalia preparation preserved in glycerol. In coll. T. \& K. Nupponen.

Distribution. Oman, Sudan, Yemen.

Remarks. The external appearance of the moth and male and female genitalia were illustrated in the original description (see Bengtsson 2002). New to Jordan and the Sinai region.

Scythris brunneofasciella K. Nupponen \& Junnilainen, 2000

Material. 1 q Russia, 5045’ N 5428’ E, Orenburg oblast, Pokrovka village $20 \mathrm{~km} \mathrm{~S}$, Schibendy valley, 220 m, 30.VIII.2000, K. Nupponen leg. In coll. T. \& K. Nupponen.

Remarks. A second specimen of this taxon was found from the type locality. The moth was discovered sitting under a rock in a very warm evening just before sunset. A late date of capture might indicate that the taxon has two generations.

Scythris camelella Walsingham, 1907

Material. 1 o Jordan South, Al'Agaba env., 300 m NN, 12-16.II.2001, leg. Krüger, Saldaitis 


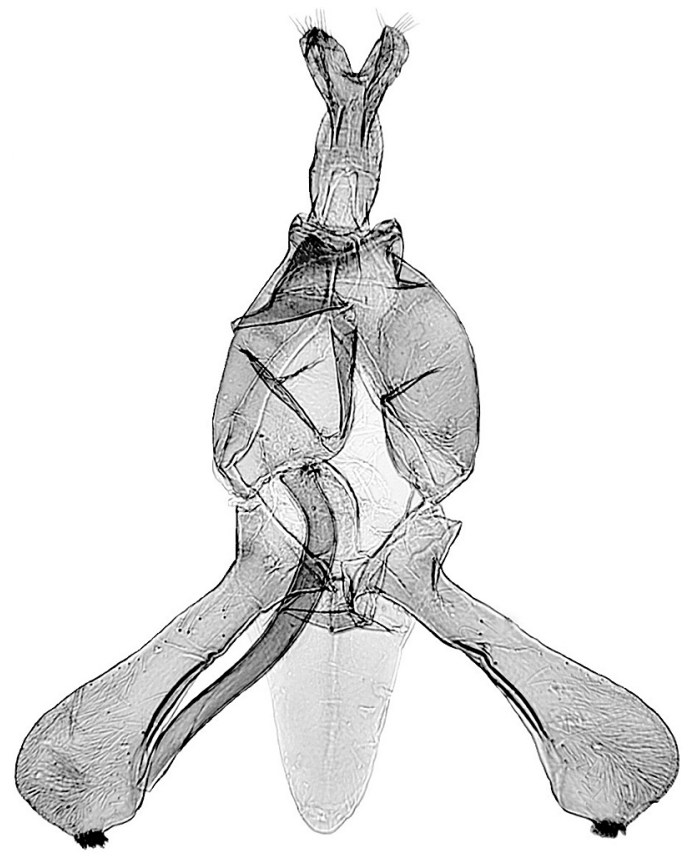

Fig. 1. Male genitalia of Scythris caroxylella Falkovitch, 1969 (Mongolia).

\& Saldaitiene. Genitalia slide: K. Nupponen prep. no. 2/08.IV.2004. In coll. T. \& K. Nupponen.

Distribution. Algeria, Egypt, Iran, Sudan, Tunisia, Yemen.

Remarks. The external appearance of the moth and male and female genitalia were illustrated by Bengtsson (1997b). New to Jordan.

\section{Scythris caroxylella Falkovitch, 1969}

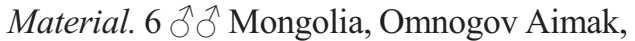
Bayandalai Somon, Zoolen uul, 1,700 m a.s.1., 27-30.V.1997, Yu. Marusik leg. Genitalia preparations: K. Nupponen prep. no. 1/11.I.2004; 2/11.I.2004. In coll. Finnish Museum of Natural History, University of Helsinki.

Remarks. There are small differences in the male genitalia between specimens originated from Mongolia and Uzbekistan, primarily in the shape of valva (Figs. 1-2; see also Falkovitch 1969). However, there seems to be minor variation in the valva even within the Mongolian population. With a little doubt I regard the Mongolian taxon to belong to Scythris caroxylella. New to Mongolia.

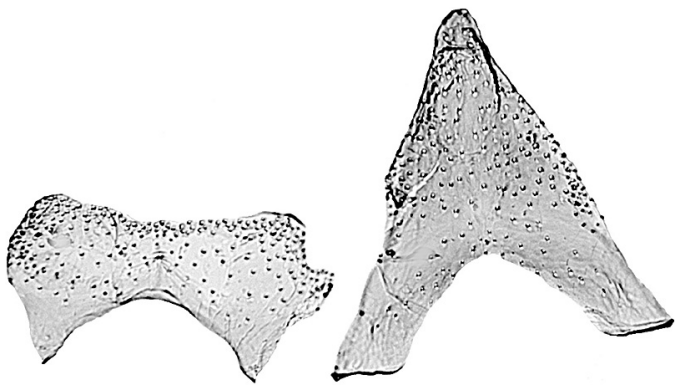

Fig. 2. Tergum VIII (left) and sternum VIII (right) of Scythris caroxylella (Mongolia).

Scythris cucullella Bengtsson, 2002

Material. 1 Ð Jordan South, Al'Agaba env., 300 m NN, 12-16.II.2001, leg. Krüger, Saldaitis \& Saldaitiene. Genitalia preparation preserved in glycerol. In coll. T. \& K. Nupponen.

Distribution. Oman, Yemen.

Remarks. The external appearance of the moth and male and female genitalia were illustrated in the original description (see Bengtsson 2002). New to Jordan.

Scythris elenae K. Nupponen, 2000

Material. 3 ㅊํ 1 q Russia, Orenburg oblast, Orenbugskij zap., Burtinskij step, 12-17.VI. 2001, J. Kullberg \& M. Zalewski leg. Genitalia preparation: K. Nupponen prep. no. 1/26.I.2003 (q). One further genitalia preparation preserved in glycerol. In coll. Finnish Museum of Natural History, University of Helsinki. 1 ते Russia, $51^{\circ} 23^{\prime} \mathrm{N} 56^{\circ} 49^{\prime} \mathrm{E}$, Orenburg oblast, Donskoje village $6 \mathrm{~km} \mathrm{~W}$, mount Verbljushka, $220 \mathrm{~m}$ a.s.1., 27.VI.2003, K. Nupponen leg. In coll. T. \& K. Nupponen.

Remarks. The description of $S$. elenae is based on a single male specimen collected from the southern Ural Mountains, Orenburg district (Nupponen et al. 2000). In 2001 four further specimens were discovered in the same region, including a previously unknown female. Additionally, one male was captured using light trap from the type locality in June, 2003. Both male and female genitalia of $S$. elenae indicate a close relationship to $S$. hamardabanica K. Nupponen, 2003 and S. juerivetei K. Nupponen (in litt.), the former known from Buryatia and the latter from Central Asia (Nupponen 2003, Nupponen et al. 2005). In the male genitalia of all three taxa, the 


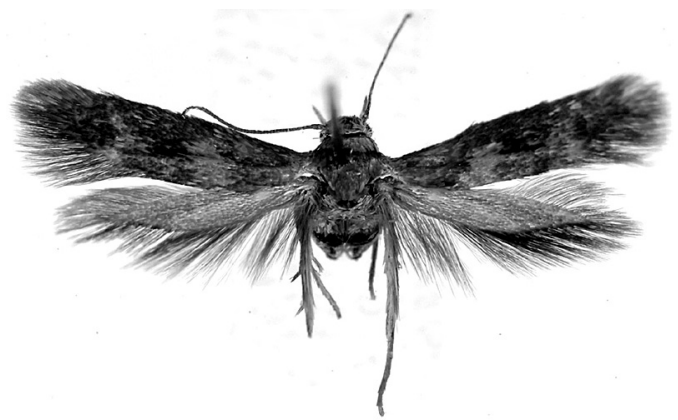

Fig. 3. Female of Scythris elenae K. Nupponen, 2003, external appearance.

distal arm of gnathos is asymmetrically united to the basal plate at left-lateral side, a characteristic difficult to see in the genitalia mounted on a slide. The female genitalia of $S$. elenae differ from those of $S$. hamardabanica and $S$. juerivetei by diverging shanks and a wide and slender anterior sclerotization of the sterigma (see below; sclerotization narrower in hamardabanica and much broader in juerivetei). A distinctive character of the female of $S$. elenae is a large, ochreous spot at the underside of hindwings, a detail separating the taxon from all known Palaearctic scythridids. The description of a female of $S$. elenae is given below.

External appearance of female (Figs. 3-4). Wingspan $8.5 \mathrm{~mm}$. Upperside of wings similar to those of a male except ochreous spots on the forewing more distinct (see Nupponen et al. 2000). At the underside of hindwing a large, elongate pale ochreous spot at midwing and scattered black scales on a pale fuscous apical part. Abdomen dorsally dark brown, basally and terminally paler; ventrally pale brown.

Female genitalia (Fig. 5). Sterigma generally U-shaped, shanks slightly diverging; anterior part with wide but narrow sclerotization around ostium; ostium well-marked, wide, situated at anterior margin of sterigma. Sternum VII quadrangular, posterior margin concave and medially with circular structure. Apophyses anteriores $0.65 \times$ length of apophyses posteriores.

Scythris eversmanni K. \& T. Nupponen, 2000

Material. SE Ukraine, Donetsk reg., Chomu-

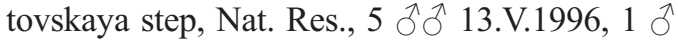
21.V.1996, A. Bidzilya leg. One genitalia prepa-

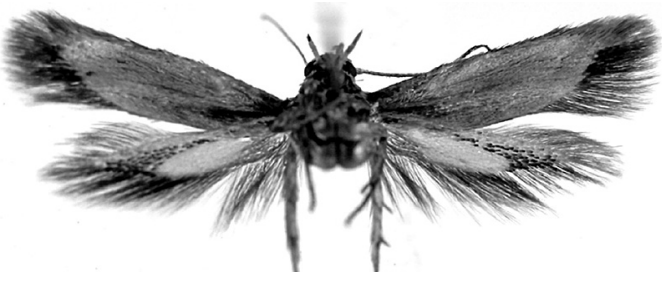

Fig. 4. Female of Scythris elenae, underside of wings.

ration preserved in glycerol. In coll. Finnish Museum of Natural History, University of Helsinki. Russia, 52³9’ N 59³4’ E, Cheliabinsk oblast, Arkaim reserve near Amurskii village, $350 \mathrm{~m}$

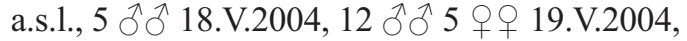
K. Nupponen leg. In coll. T. \& K. Nupponen. 1 ऽ 1 q Russia, 5109-12’ N 5802-08' E, Orenburg oblast, Orsk $40 \mathrm{~km} \mathrm{W,} \mathrm{near} \mathrm{Guberlja} \mathrm{village,} 320$ m a.s.1., 20.V.2004, K. Nupponen leg. In coll. T.

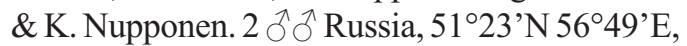

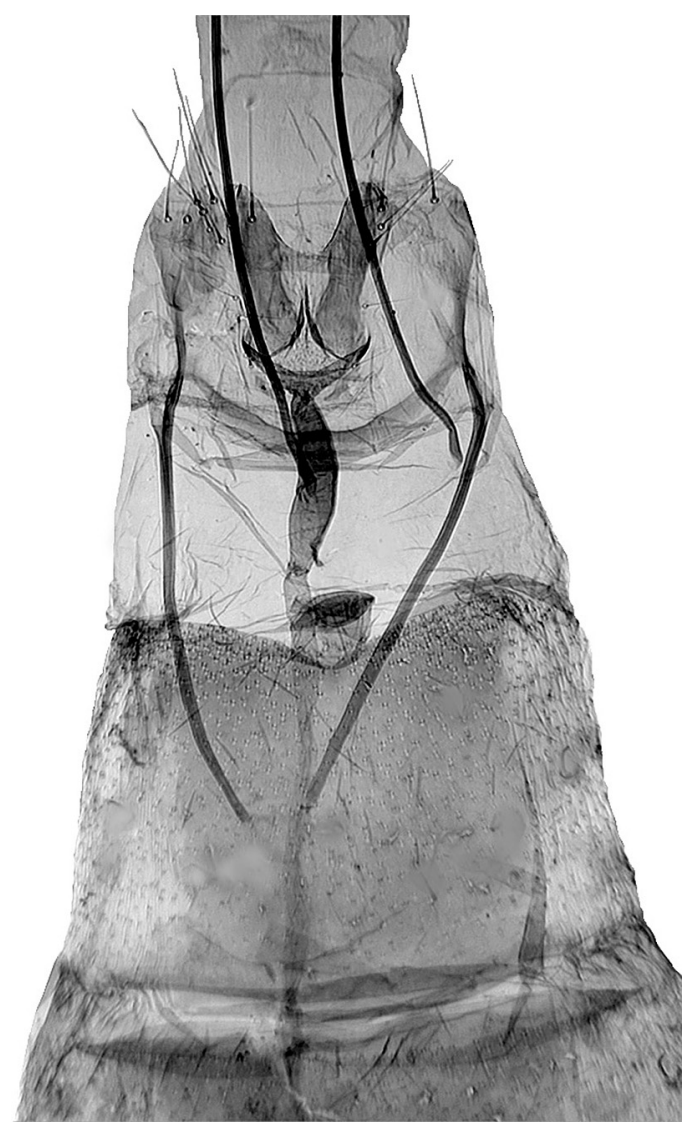

Fig. 5. Female genitalia of Scythris elenae. 
Orenburg oblast, Donskoje village $6 \mathrm{~km} \mathrm{~W}$, mount Verbljushka, $220 \mathrm{~m}$ a.s.1., 24.V.2004, K. Nupponen leg. In coll. T. \& K. Nupponen.

Remarks. The new material from southern Urals was collected in dry steppes by sweeping around flowering bushes of Caragana frutex (L.). Compared the tergal segment VIII with that of the specimens from S Ural, the heart-shaped distal portion is more 'slender' and flaps at lateral processes larger in Ukrainian specimens. New to Ukraine.

\section{Scythris hebesella sp. $\mathrm{n}$.}

Type material. Holotype $\delta$ (Fig. 6): Turkey, prov. Nevsehir, Ürgüp $3 \mathrm{~km} \mathrm{~N}, 1,100$ m a.s.l., chalk slope, 12.VI.2002, T. Nupponen leg. Genitalia slide: K. Nupponen prep. no. 3/08.X.2002. In coll. T. \& K. Nupponen. Paratypes ( 1 O , 1 ㅇ): 1 ऽ Eibes "403"; Sc. caramani ESN det.; [prep.] 1205 ESN. coll. Zool. Mus., University of Copenhagen. 1 T Turkey, prov. Nevsehir, Ürgüp 5 km NW, 17.VI.1999, J. Junnilainen leg. Genitalia slide: J. Junnilainen prep. no. 00013106. In colls. Zoological Museum, University of Copenhagen and J. Junnilainen.

Diagnosis. Externally S. hebesella sp. n. resembles $S$. albisaxella K. \& T. Nupponen, 2000, but can be separated from that by more contrastic forewings. The Eastern Palaearctic S. malozemovi K. Nupponen, 2003 differs from $S$. hebesella by more brownish forewings. A closely related S. arkaimensis Bengtsson, 2000 is much darker and it is not confused with $S$. hebesella externally. The genitalia of $S$. hebesella are very close to those of $S$. arkaimensis but differ in details. In the male genitalia of $S$. hebesella, the

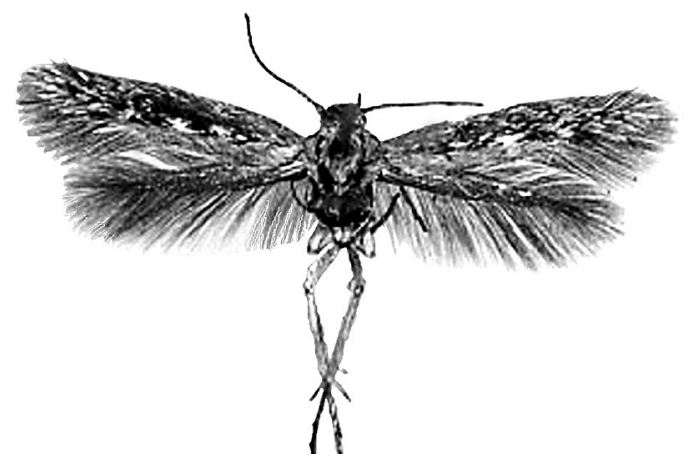

Fig. 6. Imago (holotype) of Scythris hebesella sp. n.

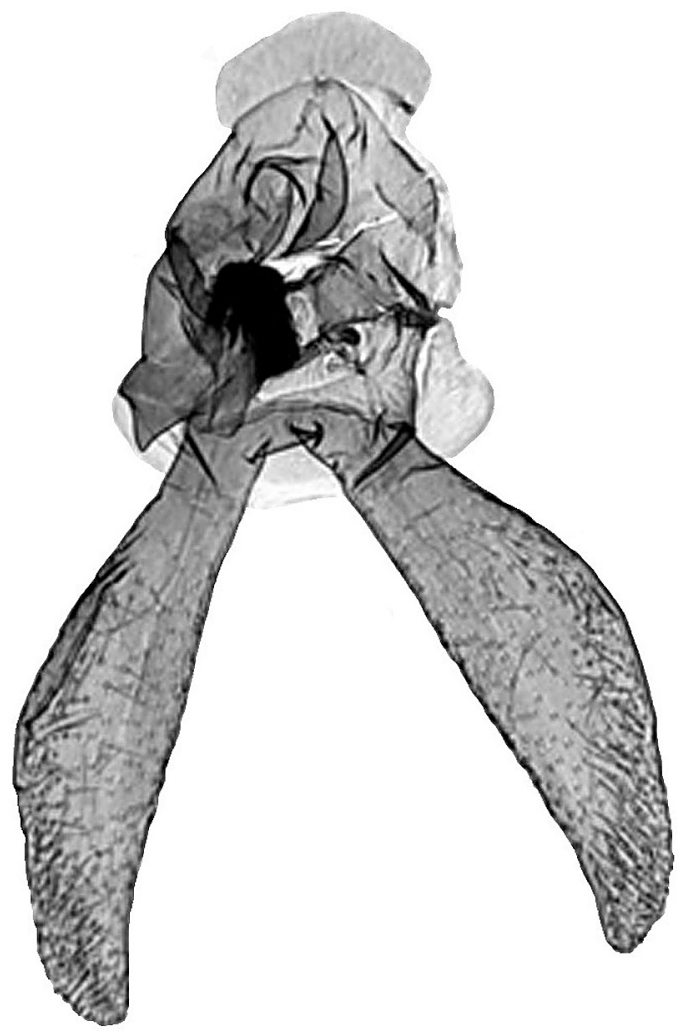

Fig. 7. Male genitalia of Scythris hebesella (holotype).

valvae are more slender and apically bent, and in tergum VIII the apex is blunt (indented in arkaimensis) and apical sclerotization of the lateral process is quadrangular (sclerotized portion rounded and covered by minute thorns in arkaimensis). In female genitalia the sterigma is narrower anteriorly, and the posterior medial incision of sternum VII is slightly deeper. (see also Sachkov 2002).

Description. Wingspan $8.5 \mathrm{~mm}$. Head, thorax, tegula and collar sand-coloured. Neck tuft dirty white. Antenna brown, scape and basal 1/3 mixed with paler scales. Haustellum laterally dirty white, otherwise sand-coloured. Labial palp: segments I and II dirty white, Segment III brown with scattered whitish scales. Abdomen fuscous. Forelegs and midlegs: femur dirty white mixed with few fuscous scales; tibia fuscous, basal $2 / 3$ with scattered pale scales; tarsus fuscous. Hindlegs dirty whitish, tibia slightly darker than femur and tarsus with a few indistinct fuscous rings. Forewing ground colour fuscous; 


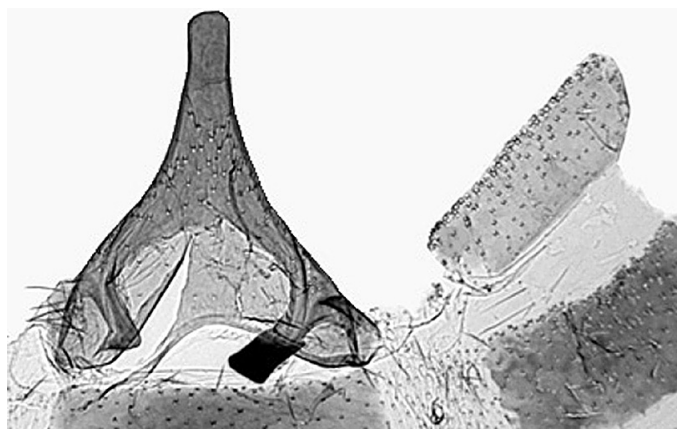

Fig. 8. Tergum VIII (left) and sternum VIII (right) of Scythris hebesella (holotype).

basal 0.1 , costal margin and area between fold and dorsal margin much paler, sand-coloured; in fold indistinct whitish streak from base to 0.75 , cut by three black spots at $0.2,0.4$ and 0.6 ; indistinct blackish spot at cell end; whole wing with scattered dirty white scales occurring more sparsely in basal and dorsal areas. Hindwing fuscous.

Male genitalia (Figs. 7-8). Uncus reduced. Gnathos asymmetrical, baggy, curved upwards, tip robust with rather large sclerotization. Tegumen extended posteriorly. Aedeagus thick and short, bottle-shaped. Valvae basally fused, slender, blade-shaped, tip slightly bent inwards; inner margin straight, outer convex. Tergum VIII subtriangular, apically elongated, tip blunt without incision; anterior margin concave; lateral processes long, smaller one digitate, larger one rather thick with strong, quadrangular apical sclerotization. Sternum VIII rectangular, $3 \times$ as wide as high.

Female genitalia (Fig. 9). Sterigma triangular, posterior portion strongly sclerotized, tip blunt; anterior indentation deep, V-shaped, inner edges sclerotized, basal corners pointed. Sternum VII subrectangular, posteriorly extended and medially incised, without sclerotization at 'bottom' of incision. Apophyses anteriores $0.6 \times$ length of apophyses posteriores. (see also Remarks).

Bionomy. The known specimens have been collected in June in hot, open chalk slopes (Fig. 10). The biology is unknown.

Distribution. Central Turkey.

Etymology. Lat. hebes = blunt. From a blunt tip of tergum VIII in the male genitalia, one of the

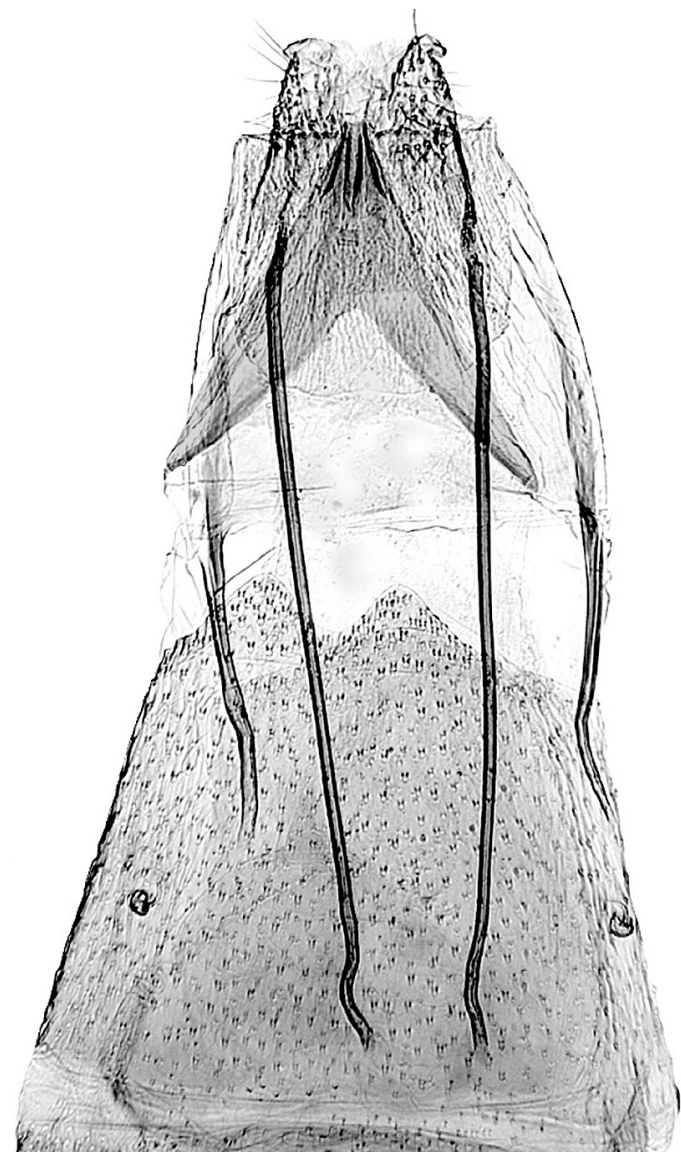

Fig. 9. Female genitalia of Scythris hebesella (paratype).

details separating the new taxon from a closely related $S$. arkaimensis.

Remarks. S. hebesella sp. n. belongs to the same species group as $S$. arkaimensis and several other Central and Eastern Palaearctic taxa (see Nupponen 2003). The single female illustrated by Junnilainen (2002) as Scythris sp. belongs to this taxon without doubt. The female specimen is less mottled than the male (holotype) and whitish scales remain only in the apical area of the forewings, evidently due to the fact that the female is slightly worn. Both specimens were collected from Central Turkey on chalk slopes located very close to each other. A male (paratype) was collected by Dr. Otto Staudinger from Turkey during the second half of the $19^{\text {th }}$ century and later dissected by Dr. Ebbe Schmidt Nielsen and misidentified as $S$. caramani (Staudinger, 1880) (B. Å. Bengtsson pers. comm.). 


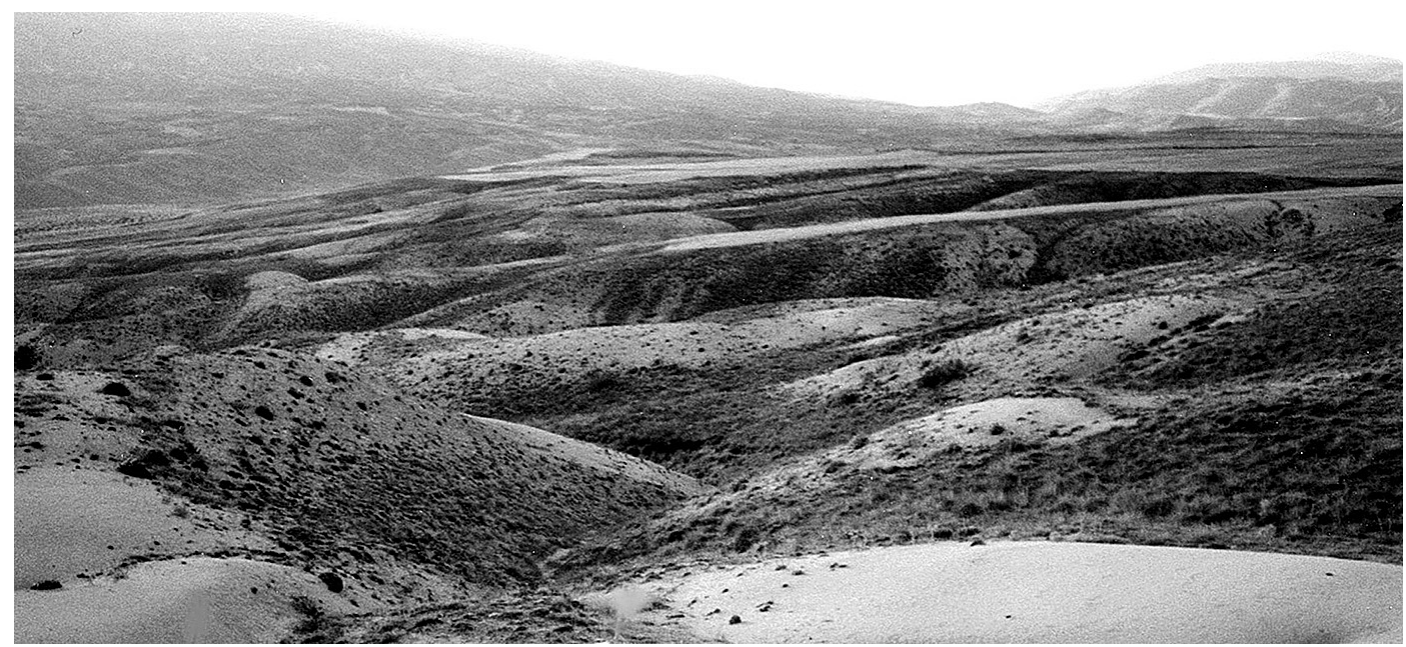

Fig. 10. Calcareous hills in the vicinity of Ürgüp, Central Turkey (1100 m a.s.I.). A habitat of Scythris hebesella sp. n.

\section{Scythris hemicycliella sp. $\mathrm{n}$.}

Type material. Holotype: đ̊ (Fig. 11): Russia, Altai Mountains, 50 $16-20^{\prime} \mathrm{N} 87^{\circ} 50-55^{\prime} \mathrm{E}$, Kuraisky Hrebet, 2,300 m a.s.1., 13.VII.2001, K. Nupponen leg. In coll. T. \& K. Nupponen. Para-

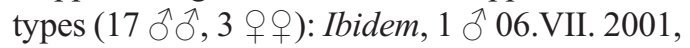
2 ठิ ふふઈ 1 q 13.VII.2001, K. Nupponen leg. Genitalia slides: K. Nupponen prep. no. 3/10.X.2002 (ふ઼), 4/10.X.2002 (), 2/17.I.2004 (ð゚), 3/17.I.2004 (ठึ), 4/17.I.2004 (ð̋), 8/17.I. 2004 (ㅇ). In coll. T. \& K. Nupponen.

Diagnosis. S. hemicycliella sp. n. forms a species complex together with $S$. bifissella (Hofmann, 1889), S. minorella Sinev, 2001 and $S$. sibirella Sinev, 2001. The prescence of a subbasal process of uncus and a large basal plate of gnathos separate the four species from the other taxa belonging to the pascuella species-group. Externally $S$. hemicycliella may be confused with many dark scythridids of equal size. The genitalia of both sexes of the four species in the bifissellacomplex are very close to each other. However, the examination of large material reveals that some characteristics in the genitalia are constant and do not overlap between the taxa. In the male genitalia of $S$. hemicycliella the valva is of constant width, the basal plate of gnathos is triangular and subbasal processes of uncus are rather small in size, more sclerotized and semicircular. In sternum VIII the angle between posterior margin of

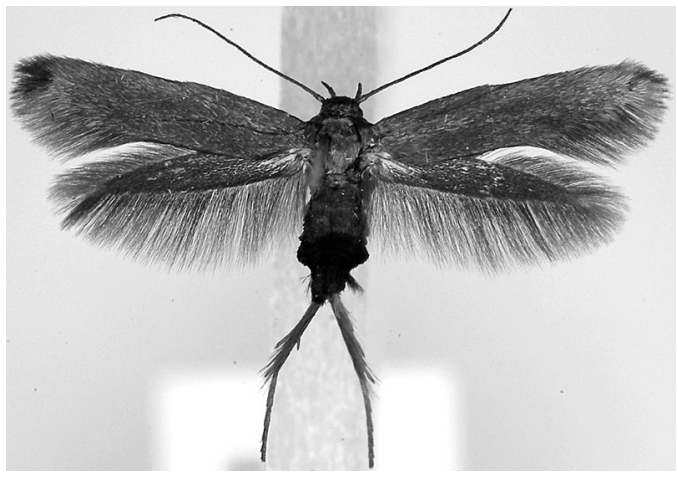

Fig. 11. Imago (holotype) of Scythris hemicycliella sp. n.

basal portion and posterior handle is about $110^{\circ}$ and posterior bifurcation extends to $0.45 \times$ length of posterior handle. Tergum VIII is similar to that of S. bifissella and S. sibirella; it is somewhat variable in these three species and cannot be used as a diagnostic character. In the female genitalia there is a widely $\mathrm{V}$-shaped fold anteriorly around ostium, posterior part of the sterigma is only slightly extended and anterior margin of sternum VII is distinctly concave. The diagnostic differences between $S$. hemicycliella, S. bifissella, S. minorella and $S$. sibirella are shown in Table 1 (see also Remarks and Figs. 14-15).

Description. Wing span 10-11 mm. Head, antenna, neck tuft, haustellum, collar, tegula, thorax and forewing dark brown, glossy with slight pur- 
Table 1. Diagnostic differences among Scythris hemicycliella, S. sibirella, S. bifissella and S. minorella.

\begin{tabular}{|c|c|c|c|c|}
\hline & S. hemicycliella & S. sibirella & S. bifissella & S. minorella \\
\hline Colour of forewings & $\begin{array}{l}\text { Dark brown, } \\
\text { unicolorous, } \\
\text { glossy }\end{array}$ & $\begin{array}{l}\text { Dark brown, } \\
\text { slightly glossy } \\
\text { with a few paler } \\
\text { scales at apical } \\
\text { area }\end{array}$ & $\begin{array}{l}\text { Dark brown } \\
\text { without gloss, } \\
\text { scattered pale } \\
\text { scales over } \\
\text { the wing }\end{array}$ & $\begin{array}{l}\text { Brown, paler than } \\
\text { the other } 3 \text { taxa, } \\
\text { scattered pale scales } \\
\text { over the wing }\end{array}$ \\
\hline $\begin{array}{l}\text { Male: subbasal } \\
\text { process of uncus }\end{array}$ & Semicircular & Rectangular & $\begin{array}{l}\text { Elongated } \\
\text { bulge, posteriorly } \\
\text { extended and } \\
\text { less sclerotized }\end{array}$ & $\begin{array}{l}\text { Weakly sclerotized } \\
\text { flap extending } \\
\text { to tip of prong }\end{array}$ \\
\hline $\begin{array}{l}\text { Male: basal plate } \\
\text { of gnathos }\end{array}$ & $\begin{array}{l}\text { Triangluar, } \\
\text { large }\end{array}$ & Triangular & $\begin{array}{l}\text { Roundish, } \\
\text { posteriorly } \\
\text { concave }\end{array}$ & $\begin{array}{l}\text { Trapezoid, post. } \\
\text { margin concave } \\
\text { and medially with } \\
\text { sclerotized flap }\end{array}$ \\
\hline $\begin{array}{l}\text { Male: distal arm } \\
\text { of gnathos }\end{array}$ & $\begin{array}{l}\text { Slightly sigmoid, } \\
\text { tip bent }\end{array}$ & $\begin{array}{l}\text { Straight, } \\
\text { tip hooked }\end{array}$ & $\begin{array}{l}\text { Slightly sigmoid, } \\
\text { tip bent }\end{array}$ & $\begin{array}{l}\text { Slightly sigmoid, } \\
\text { tip bent }\end{array}$ \\
\hline $\begin{array}{l}\text { Male: shape } \\
\text { of valva }\end{array}$ & $\begin{array}{l}\text { Of constant width, } \\
\text { tip rounded }\end{array}$ & $\begin{array}{l}\text { Broadest at middle, } \\
\text { tip obliquely cut off }\end{array}$ & $\begin{array}{l}\text { Claviform, } \\
\text { tip rounded }\end{array}$ & $\begin{array}{l}\text { Thick, broadest } \\
\text { at middle, subapically } \\
\text { tapered and bent } \\
\text { inwards, tip cut off }\end{array}$ \\
\hline $\begin{array}{l}\text { Sternum VIII of male: } \\
\text { angle between post. } \\
\text { margin of basal portion } \\
\text { and post. handle }\end{array}$ & $110^{\circ}$ & $125^{\circ}$ & $135^{\circ}$ & $135^{\circ}$ \\
\hline $\begin{array}{l}\text { Sternum VIII of male: } \\
\text { incision of post. handle }\end{array}$ & $\begin{array}{l}0.45 \times \text { length } \\
\text { of post. handle }\end{array}$ & $\begin{array}{l}0.5 \times \text { length } \\
\text { of post. handle }\end{array}$ & $\begin{array}{l}0.4-0.65 \times \text { length } \\
\text { of post. handle }\end{array}$ & $\begin{array}{l}0.9 \times \text { length } \\
\text { of posterior handle, } \\
\text { furcation arms } \\
\text { diverging }\end{array}$ \\
\hline $\begin{array}{l}\text { Male: length } \\
\text { of aedeagus }\end{array}$ & $\begin{array}{l}0.9 \times \text { length } \\
\text { of valva }\end{array}$ & $\begin{array}{l}0.9 \times \text { length } \\
\text { of valva }\end{array}$ & $\begin{array}{l}0.9 \times \text { length } \\
\text { of valva }\end{array}$ & $\begin{array}{l}1.1 \times \text { length } \\
\text { of valva }\end{array}$ \\
\hline $\begin{array}{l}\text { Female: horizontal flap } \\
\text { anteriorly around ostium }\end{array}$ & Widely V-shaped & $\begin{array}{l}\text { V-shaped, } \\
\text { right-angled }\end{array}$ & Absent & Absent \\
\hline $\begin{array}{l}\text { Female: post. extension } \\
\text { of sterigma }\end{array}$ & Slight, triangular & $\begin{array}{l}\text { Large, subtrap- } \\
\text { ezoid, post. margin } \\
\text { concave }\end{array}$ & Large, triangular & Slight, convex \\
\hline $\begin{array}{l}\text { Female: post. margin } \\
\text { of sternum VII }\end{array}$ & $\begin{array}{l}\text { Almost straight; } \\
\text { process large, } \\
\text { elongated }\end{array}$ & $\begin{array}{l}\text { Straight with } \\
\text { U-shaped medial } \\
\text { incision; medial } \\
\text { process wide } \\
\text { and short }\end{array}$ & $\begin{array}{l}\text { Medially slightly } \\
\text { concave; medial } \\
\text { process large, } \\
\text { elongated }\end{array}$ & $\begin{array}{l}\text { Medially slightly } \\
\text { concave; medial } \\
\text { process roundish }\end{array}$ \\
\hline $\begin{array}{l}\text { Female ant. margin } \\
\text { of sternum VII }\end{array}$ & Distinctly concave & Almost straight & Medially concave & Straight \\
\hline
\end{tabular}

plish-olive tinge. Labial palp: segment I and basal part of segment II pale fuscous, otherwise dark brown with a few pale scales. Abdomen in both sexes fuscous, dorsal side darker and slightly glossy. Legs dark fuscous. Hindwing fuscous with slight purplish hue near margins.

Male genitalia (Fig. 12). Uncus two long, ba- sally united digitate prongs; lateral margin subbasally with sclerotized and furrowed semicircular processes. Basal plate of gnathos triangular; distal arm rather long, slightly sigmoid, apically bent and pointed. Aedeagus long, medially slightly bent, apically tapered. Valva of constant width, curved, apex rounded. Vinculum large, X- 


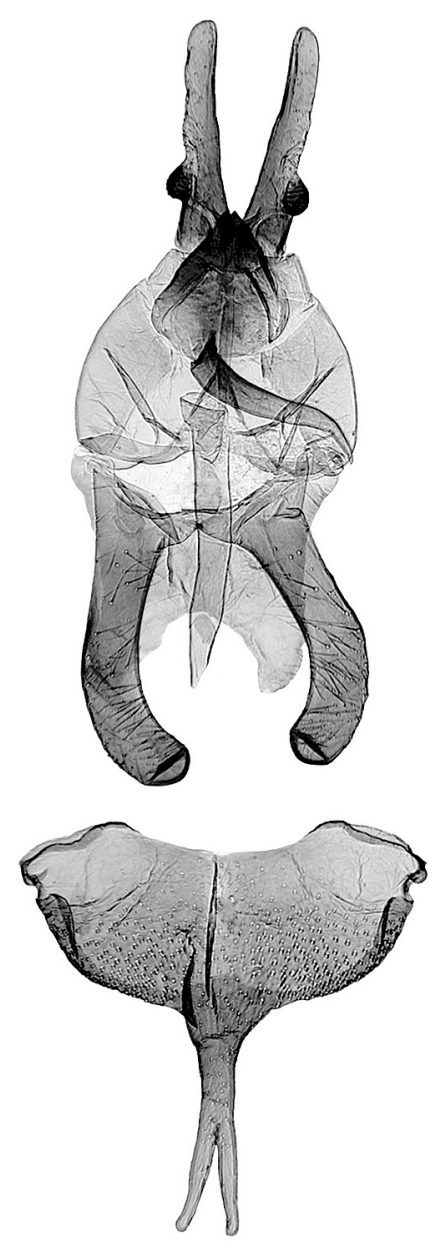

Fig. 12. Male genitalia (up) and sternum VIII (down) of Scythris hemicycliella (paratype).

shaped plate. Tergum VIII subquadrangular, rather membranous. Sternum VIII subtriangular, posteriorly bifurcate up to $0.45 \times$ length of posterior handle; angle between posterior margin of basal portion and posterior handle about $110^{\circ}$.

Female genitalia (Fig. 13). Sterigma semicircular, posterior margin slightly extended; at middle more sclerotized horizontal flap and anteriorly around ostium widely V-shaped fold. Sternum VII rectangular; anterior margin concave; posterior margin almost straight, medially with elongated, rimmed process. Apophyses anteriores $0.5 \times$ length of apophyses posteriores.

Bionomy. The moths were collected in the first half of July by sweeping at daylight, from 6 a.m. up to 9 p.m. The habitat is an alpine meadow at the elevation of $2,300 \mathrm{~m}$. The biology is unknown.

Distribution. Russia (Altai Mountains).

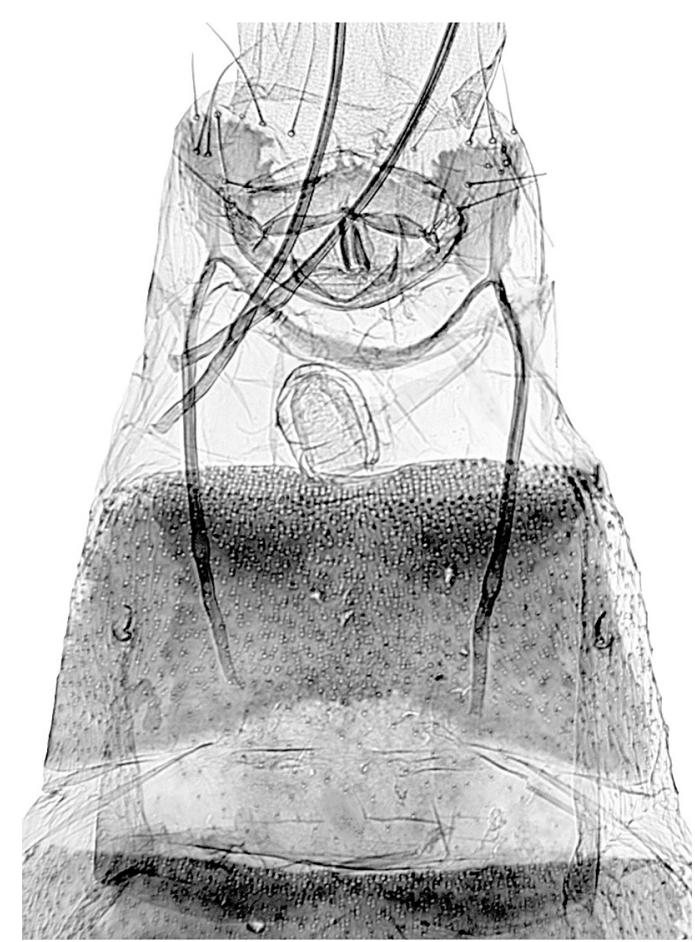

Fig. 13. Female genitalia of Scythris hemicycliella (paratype).

Etymology. Gr. hemicyclium $=$ semicircle. From a semicircular subbasal process of uncus in the male genitalia, one of the details separating the new species from closely related taxa.

Remarks. S. hemicycliella sp. n. belongs to the pascuella species group. A great similarity both in the external appearance and morphology of the genitalia between $S$. bifissella, $S$. minorella, $S$. sibirella and the new taxon has caused misunderstandings in the literature, mainly because the Siberian taxa are scarce in collections and reference material has not been available. S. bifissella, reported from the Altai Mountains by Nupponen \& Nupponen (2001), represents S. sibirella, and a single specimen from Tuva Republic stated as S. bifissella by Bengtsson (1997a) is S. minorella without doubt (see also Bengtsson 1997b). It is possible that $S$. bifissella has its eastern border of the distribution range in the Ural Mountains. I haven't seen any correctly determined specimens of bifissella originated from Siberia, despite examining large material of the group from different parts of Russia (bifissella $>100$ exx.; minorella 49 exx.; sibirella 30 exx.; hemicycliella 21 exx.). In 
Fig. 14. Male genitalia (up) and sternum VIII (down) of the bifissellacomplex. Left: S. sibirella (Altai). Middle: $S$. bifissella (S Ural).

Right: S. minorella (S Buryatia).

Fig. 15. Female genitalia of the bifissella-complex. Left: S. sibirella (Altai). Middle: S. bifissella (S Ural). Right: $S$. minorella (S Buryatia).
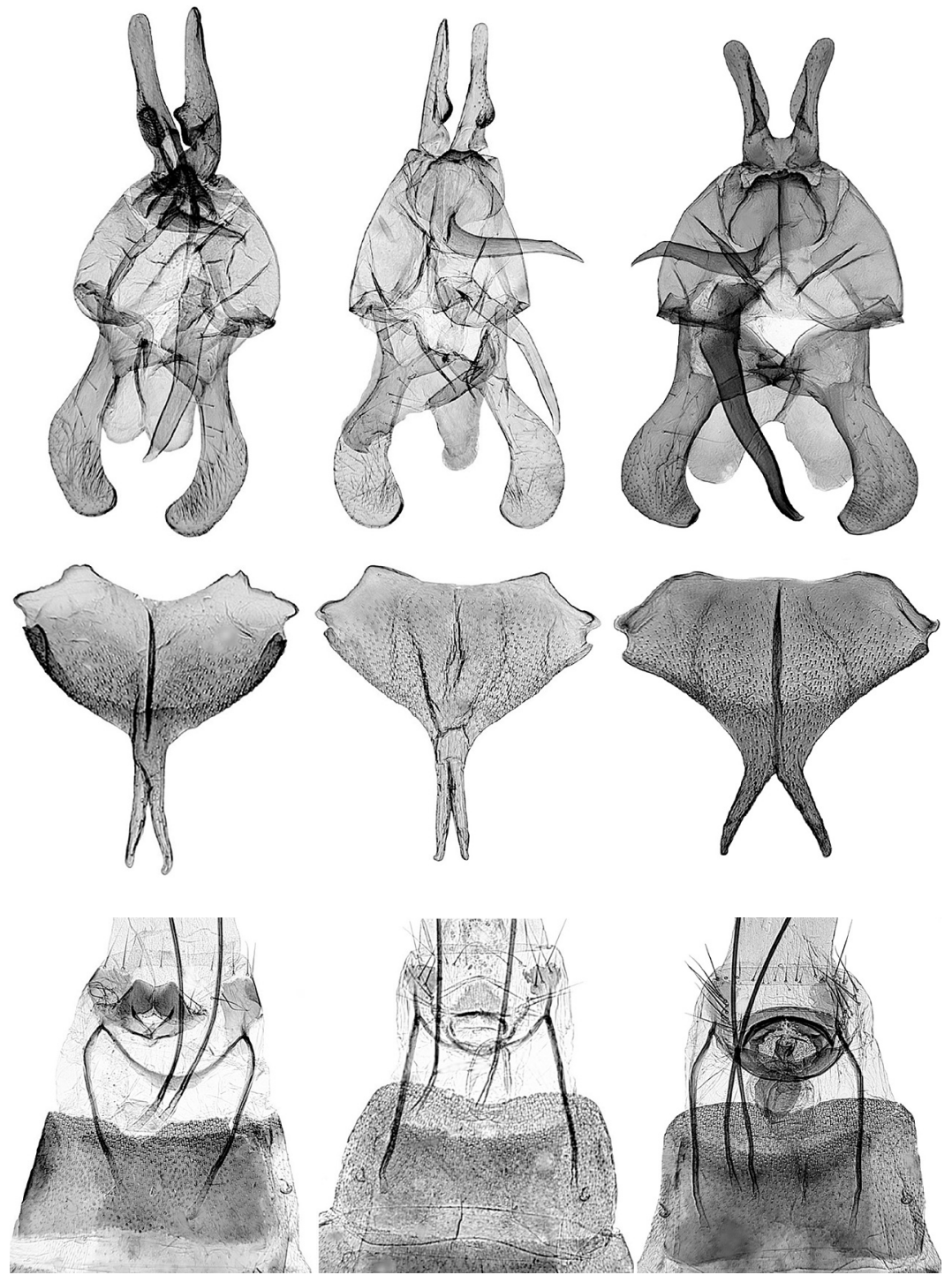

300 m NN, 12-16.II.2001, leg. Krüger, Saldaitis \& Saldaitiene. Genitalia slide: K. Nupponen prep. no. 1/08.IV.2004. In coll. T. \& K. Nupponen.

Distribution. Israel, Iran, Oman, Saudi-Arabia.

Remarks. New to Jordan.

Scythris luxatiella K. Nupponen \& Kaitila, 2000

Material. 1 ○ึ Russia, Orenburg oblast, Orenbugskij zap., Burtinskij step, 12-17.VI.2001, J. Kullberg \& M. Zalewski leg. In coll. Finnish Museum of Natural History, University of Hel-

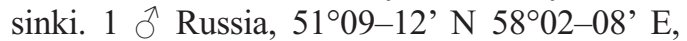


Orenburg oblast, Orsk $40 \mathrm{~km} \mathrm{~W}$, near Guberlja village, 320 m a.s.1., 26.VI.2003, K. Nupponen leg. In coll. T. \& K. Nupponen.

Remarks. Since the discovery of the taxon in 1997, two further specimens have been found from new localities in Orenburg district. The species is so far known only from foothills of the southern Ural Mountains.

Scythris olschwangi K. \& T. Nupponen, 2000

Material. 3 충ํ 2 우 Russia, $50^{\circ} 45^{\prime} \mathrm{N}$ $54^{\circ} 28^{\prime} \mathrm{E}$, Orenburg oblast, Pokrovka village 20 $\mathrm{km} \mathrm{S}$, Schibendy valley, $190 \mathrm{~m}$ a.s.1., 11.VI.2001, K. Nupponen leg. In coll. T. \& K. Nupponen.

Remarks. Five specimens of this rare taxon found from the same valley where the species was discovered in 1998. The new place is located 7 $\mathrm{km}$ to the south from the original spot. S. olschwangi is so far known only from Scibendy valley in the southern Ural region.

\section{Scythris spinella K. \& T. Nupponen, 2001}

Material. 1 \& Russia, Altai Mountains, 50¹6-20' N 8750-55' E, Kuraisky Hrebet, 2,300 m a.s.1., 10.VII.2001, K. Nupponen leg. (Paratype; see Remarks). In coll. T. \& K. Nupponen.

Remarks. The specimen is included in the type series, but erroneously not mentioned in the original description. The moth was captured from the same locality as the other known specimens. Thus, altogether 6 exx. ( $4 \hat{\jmath} \hat{\jmath}, 2$ of $)$ are included in the type series (see also K. \& T. Nupponen 2001). S. spinella is known only from Kurai range at high altitudes of the Altai Mountains.

Acknowledgements. I thank Mr. Bengt $\AA$. Bengtsson (Färjestaden, Sweden) for fruitful discussions concerning the present material, Dr. Lauri Kaila (Helsinki, Finland), Mr. Jari Junnilainen (Vantaa, Finland) and Mr. Aidas Saldaitis (Vilnius, Lithauania) for loan of material, Mr. Kimmo
Silvonen (Espoo, Finland) for his help in processing the photographs and Dr. Marko Nieminen (Tampere, Finland) for useful comments on the manuscript.

\section{References}

Bengtsson, B. Å. 1997a: Notes on interesting scythridids in the Zoological Museum, Helsinki, Finland (Lepidoptera, Scythrididae). - Entomol. Fennica 8: 89-102.

Bengtsson, B. A. 1997b: Scythrididae. — In: Huemer, P., Karsholt, O. \& Lyneborg, L. (eds.), Microlepidoptera of Europe 2: 1-301.

Bengtsson, B. Å. 2002: Scythridids of the Arabian Peninsula, I: Oman (Lepidoptera, Scythrididae). — Phegea 30(3): 105-118.

Falkovitch, M. I. 1969: O pishchevykh svyazakh pustinnykh cheshuekrylykh (Lepid.) v srednei Azii. [About trophic relationships in Lepidoptera from steppe areas of Middle Asia]. In Doklady na dvatsat'pervom ezhegodnom chtenii pamyati N.A. Cholodkovskogo. - Akademiya Nauk SSSR. Vsesoyuznoe Entomologicheskoe Obshchestvo (1968): 53-88. [In Russian]

Junnilainen, J. 2002: Three new species of Scythrididae from central Turkey (Lepidoptera: Scythrididae). Entomol. Fennica 13: 146-152.

Nupponen, K. 2003: Contribution to the scythridid fauna of southern Buryatia, with description of seven new species (Lepidoptera: Scythrididae). - Entomol. Fennica 14: 25-45.

Nupponen, K., Bengtsson, B. Å., Kaitila, J.-P., Nupponen, T., Junnilainen, J. \& Olschwang, W. 2000: The scythridid fauna of the southern Ural Mountains, with description of fourteen new species (Lepidoptera: Scythrididae). - Entomologica Fennica 11: 5-34.

Nupponen, K., Jürivete, U. \& Pototski, A. 2005: Records of scythridids from Southeastern Kazakhstan, with description of five new species (Lepidoptera: Scythrididae). - Entomol. Fennica 16: 65-73.

Nupponen, K. \& Nupponen, T. 2001: Notes on the scythridid fauna of the Altai Mountains, with description of four new species (Lepidoptera: Scythrididae). — Entomol. Fennica 12: 81-93.

Sachkov, S. A. 2002: A new and a little-known species of Scythris Hübner, 1825 (Lepidoptera: Scythrididae) from Kazakhstan and the Middle Volga, and three species of Scythris newly synonymized. - Entomologist's Gazette 53: 259-264. 